\title{
Colored Surface Vector Maps and Their Stereoscopy to Extract Geomorphological Features
}

\author{
Takako NAKAMURA* and Tetsuya SHOJI*
}

\begin{abstract}
When a normal vector of slope surface ("surface vector" here) is shown as a point on a Wulff's net overlaying the basal plane of the HSI color cone, the vector is displayed by a color on a map. Accordingly, this map shows spatial distribution of surface vectors, each of which represents a slope direction and a slope degree at a point. The surface vector map is very useful to extract geomorphological features such as faults, linear structures, ring structures and others. If a stereo-pair of a surface vector map showing topography is provided, characteristic geomorphologies are extracted easier.
\end{abstract}

Key word : Surface vector, Wulff's net, HSI color cone, Stereo-pair

\section{1.はじめに}

地形から断裂帯や環状構造などを抽出するとき，地表面 の傾斜は重要な情報を提供する。線形構造をはじめとする 特徵的地形を把握するために標高図を眺めることや空中写 真を立体視することは, 以前から知られている有効な手段 である.最近では，コンピュータの発達に伴ってデジタル 標高モデル（DEM：Digital Elevation Model）の整備が進 み，それらを用いた地形解析も活発に行われている。それ は，地形情報がアナログからデジタルに変化したことによ り, 地形の変化量の数值解析や, 空間情報の表示システム である GISを利用した解析結果の管理・表示が容易に行え るようになったからである。

デジタル標高モデルを用いた地形解析は，それらを白黒 の濃淡画像とし，それらの画像のフィルタリングを行うこ とによって地形の特徵を抽出する手法（例えば, 岩橋, 1992）や複数の光源を想定した陰影図を作成して，エッジ 強調処理法により谷を抽出する手法（例えば, 羽坂ほか, 1991），傾斜量図などの，特定の地形情報を強調表示した 画像を作成し, 地質構造解析, すなわち, ニアメントの 抽出を行う（例えば，田中ほか，1985；神谷ほか，2000） などの方法が主流である。また, 人工衛星や空中写真など の画像を利用した，断裂系評価のためのリニアメント抽出 も数多く行われている（例えば，大地ほか，1987；井上ほ か, 1992).このような, デジタル画像処理によるリニア メントの抽出は, 地形の不連続点が線状に配列する地形形
状（Hobbs,W.H., 1904）を，画像の濃淡の急激な変換点の 連続として抽出するものである.

以上述べた各種手法のうち，傾斜量図を考えると，これ は3 次元の単位べクトルである斜面の法線ベクトル（以下 「斜面ベクトル」）のうち，鉛直方向からの角度のみを表現 していて，方位が表現されていない。このため，傾斜量図 で環状構造が抽出されても，その内部が盛り上がっている のか, 落ち窪んでいるのか分からない。この盛り上がりか 落ち窪みかを知るためには, 別に㓌影図などが必要とな る。このとき傾斜方位図であっても，この判断は可能であ る(ただ，傾斜方位図はあまり一般的ではない)。本研 究では，この傾斜量図と傾斜方位図を1枚の図面として表 現する方法を開発した。

ところで，一般的な色は，光の 3 原色である赤 $(\mathrm{R})$ ，緑 (G)，青（B）と，それらの補色であるシアン (C)，マゼ ンダ $(\mathrm{M})$, 黄 $(\mathrm{Y})$, および，黒 $(\mathrm{K})$ ，白（W）の 6 点を 頂点とする RGB立方体内の一点として表される，今，Kと $\mathrm{W}$ を結ぶ直線を $\mathrm{I}$ 軸として，この立方体の R， Y， G， C， $\mathrm{B} ， \mathrm{M}$ を，W を含み $\mathrm{I}$ 軸に直交する平面に投影すると，正 六角形ができる。この正六角形を円に変換し，その円を底 面とし，Kを頂点とした円錐をHSI 円錐カラーモデルとい う。この円錐の底面をウルフ網と一致させることで， ウル フ網上の 1 点として与えられる斜面ベクトルを色で表わす ことができる，この色を地図上に表示することにより，傾 斜方向と傾斜量の空間分布を同時に表現することができる. 
このようにして作成した斜面ベクトル図を，地形が立体視 できる立体視対として表現すると，特徵的地形がより容易 に抽出できる。ここでは，デジタル標高モデルから陰影 図, 傾斜量図, 傾斜方位図を作成し, 斜面ベクトル図と比 較・評価することによって, 斜面ベクトル図の有効性を検 証する。

\section{2. 使用データ}

斜面べクトル図がさまざまな特徵的地形の抽出に有効で あることを示すために，1997年に国土地理院から刊行され

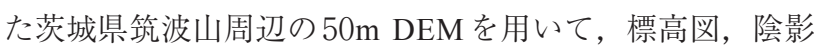
図，傾斜方位図，傾斜量図，斜面べクトル図，斜面ベクト ル図の立体視対を作成した。また，特に断裂系と環状構造 に対する斜面ベクトル図と斜面ベクトル図の立体視対の効 果を検証するために, 大分県万年山周辺と, 青森県と秋田 県の県境に位置する十和田湖周辺の傾斜量図と斜面ベクト ル図の立体視対も作成した。筑波山周辺は，平野と山地が 比較的明暸に分かれた地形を示す。豊肥地域は日本最大の 活火山地带であり, 火山地形と東西に走る大小規模の正断 層が発達している。十和田湖はカルデラであり, 環状構造 の例として選んだ。

\section{3. 斜面ベクトル図の作成方法}

DEM の画像処理演算にはCompaq VF(Visual Fortran) Ver.6.6を, 計算結果の画像表示にはAdobe Photoshop Ver.6.0を用いた。

\section{1. 斜面ベクトル}

$50 \mathrm{~m}$ DEM から斜面ベクトルを算出した。筑波山周辺の DEMの格子点間隔は，東西（緯線）方向が約 $56.0 \mathrm{~m}$, 南北 (経線) 方向が約 $46.3 \mathrm{~m}$ である. 斜面ベクトルの傾斜方向と 傾斜角は，対象とする格子点を中心とする 9 個の格子点に 近似平面を当てはめ, その法線から求めた。

直交座標系で求めた法線ベクトルの傾斜方向 $(\theta)$ と傾斜 角 $(\phi)$ は次式で与えられる.

$$
\begin{aligned}
& \theta^{\prime}=\cos ^{-1}\left(\frac{a}{\sqrt{a^{2}+b^{2}}}\right) \\
& b \geqq 0 \text { のとき } \\
& \theta=\theta, \\
& b<0 \text { のとき } \\
& \theta=2 \pi-\theta, \\
& \phi=90-\tan ^{-1}\left(\frac{1}{\sqrt{a^{2}+b^{2}}}\right)
\end{aligned}
$$

ここで, $a$ と $b$ は近似平面 $z=a x+b y+c$ の係数である.

\section{2. 斜面ベクトルのステレオ投影と HSI色空間}

斜面ベクトルの空間分布を地形図上に表現するために, 色相 (H：Hue), 彩度 (S : Saturation), 明度 (I : Intensity) の 3 成分で構成されるHSI 円錐カラーモデルを利用した. ウルフ網と HSI 円錐カラーモデルの底面を対応させたとき， 斜面ベクトル $(\theta, \phi)$ のステレオ投影点と HS 面の座標 （H，S）は次のように対応する。

$$
H=\theta
$$

$$
S=\tan \frac{\phi}{2}
$$

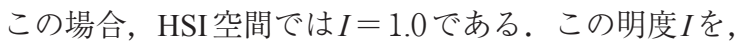

$$
I=I_{0}+\left(1-I_{0}\right) \times S \quad\left(0 \leqq I_{0} \leqq 1.0\right)
$$

とすることもできる。ここで， $I_{0}$ は円錐の頂点の明度であ る。適当な $I_{0}$ を与えると, 傾斜角度が明度でも表現され る. $I_{0}$ は図が見やすくなるように任意に決めればよい， $I_{0}$ が1.0，0.5，0.0のときのウルフ網を第 1 図に示す.

ところで，実際に斜面ベクトルの傾き角が $0{ }^{\circ} に$ に近くなる ことはほとんどないので，(2)式だとHSI 円錐カラーモデル の底面を有効に使えない，そこで，申に最大傾斜を与える $\phi_{\text {max }}$ を代入し, $S$ の最大輝度 $S_{\text {steepest }}$ を,

$$
S_{\text {steepest }}=\tan \frac{\phi_{\max }}{2}
$$

とすると, HSI 円錐カラーモデルの底面で高輝度の部分を 有効に使うことができる。

\section{3. 立体視対の作成}

斜面ベクトルを表現する図で，同時に地形の起伏を表現 したい場合，斜面べクトル図と地形の起伏情報との重㸚合 わせが必要である。地形の起伏は，しばしば陰影図として 表示される。そこで，斜面べクトルはHS面で表し，Iを陰 影図に利用することが可能である。しかし，この場合，当 然のことながら, 明度の変化として斜面べクトル図を表現 することはできない。この欠点を除くために, 斜面べクト ルを示す色で地表面を着色し，この地形の立体視対を作成 した。これを斜面べクトル図の立体視対と呼ぶ。立体視対 は，左目で見た像と，右目で見た像の 2 枚の画像からな る。この対画像をそれぞれの目で見ることにより，脳内で 3 次元像が認識される.

\section{4. 結果と考察}

筑波山周辺の標高図, 陰影図, 傾斜方位図, 傾斜量図, 斜面ベクトル図を第 2 図に，斜面ベクトルの立体視対を第 3 図に示寸。傾斜方位図は, 傾斜方向 $(\theta)$ に円形カラー チャートの $S=1.0$ のときの色を割り当てて表示してある. 傾斜量図は，傾斜角 $(\phi)$ が $0^{\circ}$ を白， $90^{\circ}$ を黒とする 255 ～ 0 の濃淡值に変換して表示してある。第 2 図と第 3 図の 


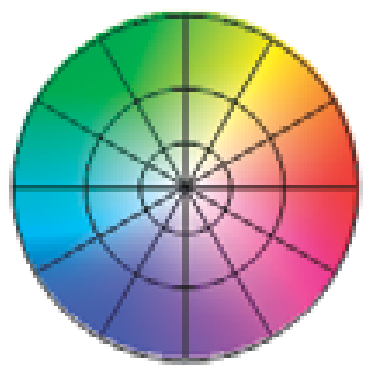

$I_{0}=1.0$

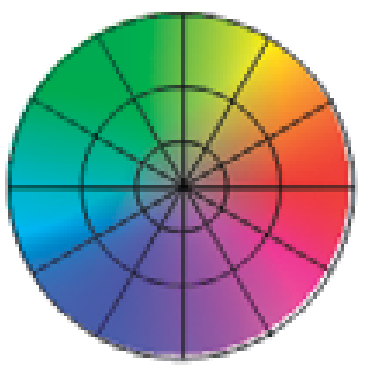

$I_{0}=0.5$

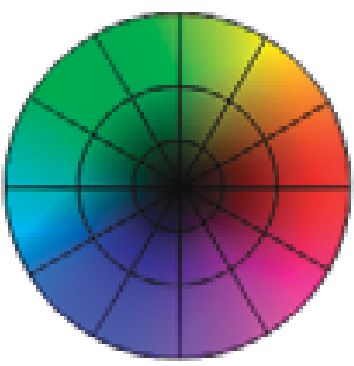

$I_{0}=0.0$

第 1 図 HSI円錐カラーモデルで着色されたウルフ網. 左から, 円錐カラーモデルの明度が $\mathrm{I}_{0}=1.0,0.5 ， 0.0$. ウ ルフ網の経線と緯線の間隔はそれぞれ $30^{\circ}$.

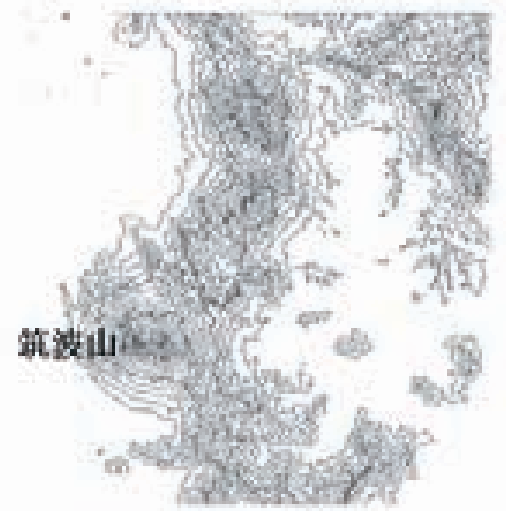

a 標高図

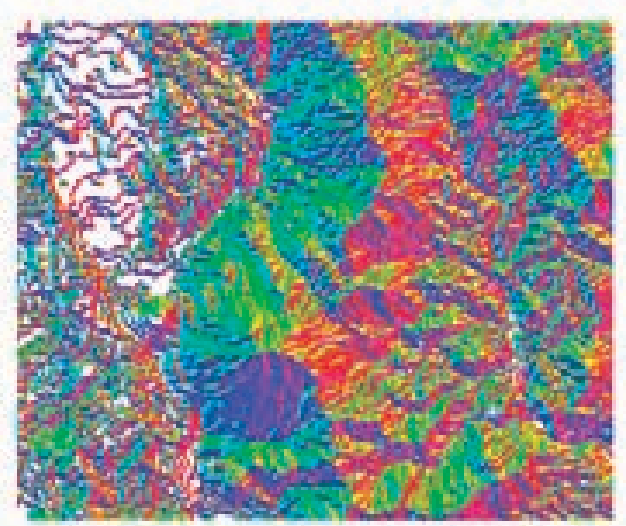

c 傾斜方位図

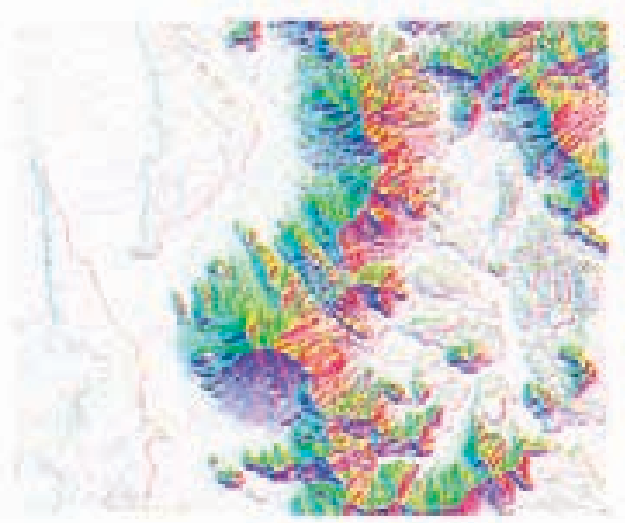

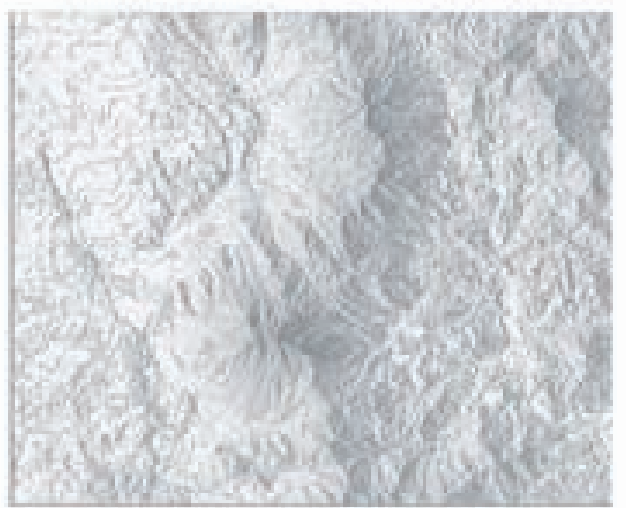

b 除影図

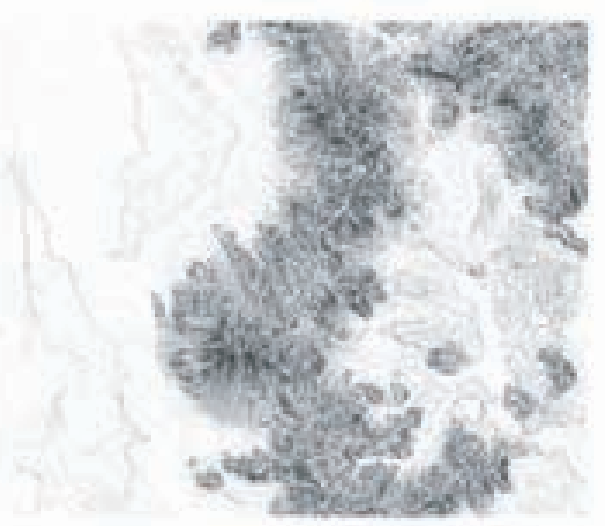

d 傾斜量図

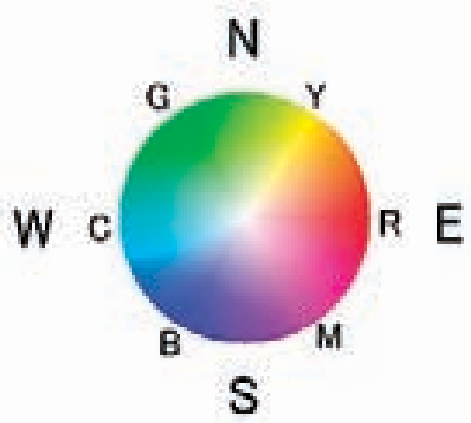

e 傾斜ベクトル図

第 2 図 筑波山周辺の地形解析図（東西約 $22.4 \mathrm{~km}$ ，南北約 $18.5 \mathrm{~km}$ ) 

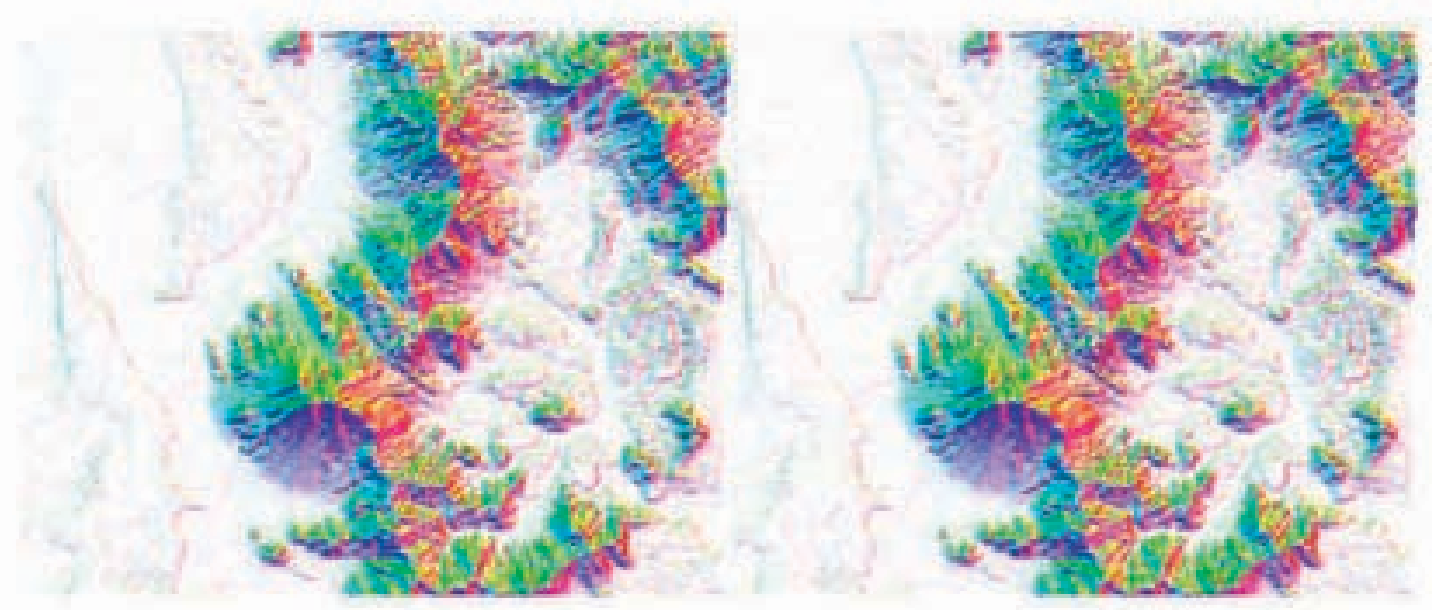

第 3 図 筑波山周辺の立体視図（東西約 $22.4 \mathrm{~km} ，$ 南北約 $18.5 \mathrm{~km}$ ）
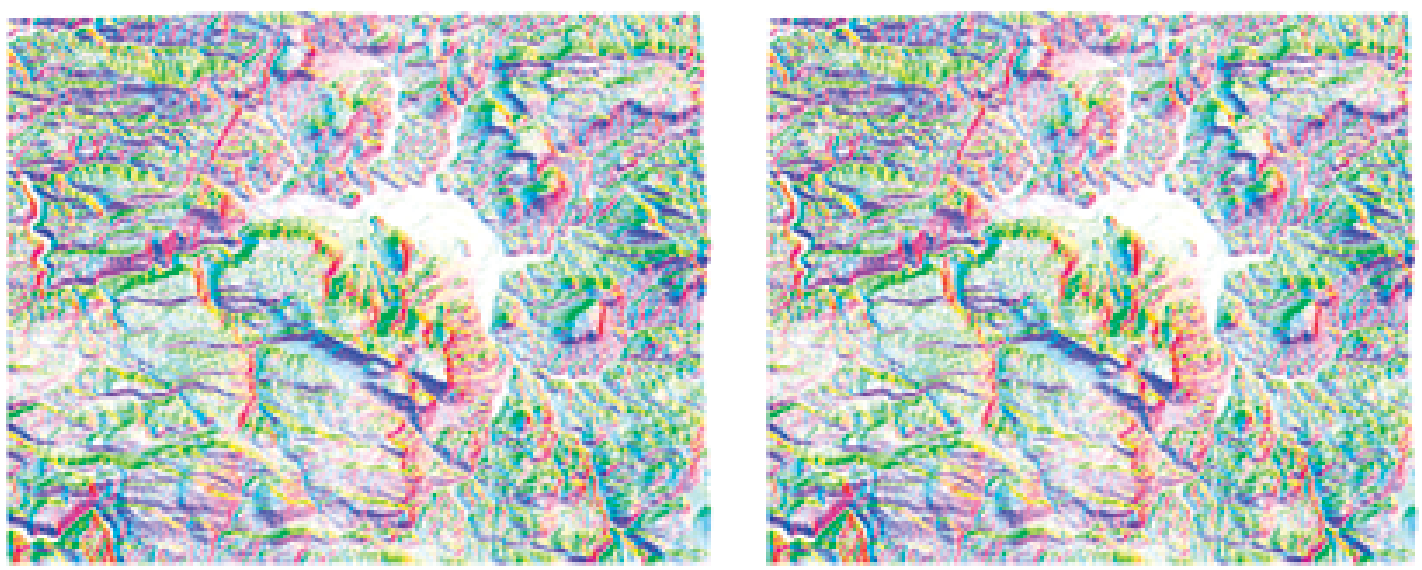

第 5 図 大分県万年山周辺の斜面ベクトルの地形立体視図（東西約 $23.3 \mathrm{~km} ，$ 南北約 $18.5 \mathrm{~km}$ ）

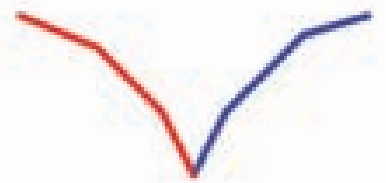

（a）傾斜方位図

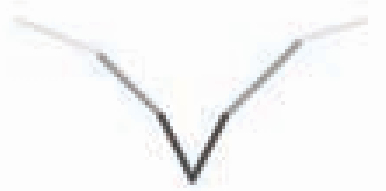

（b）傾 斜量図

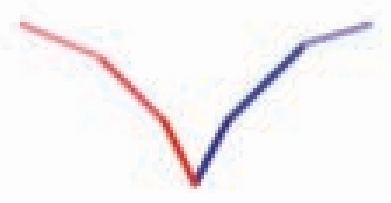

（c）傾斜ベクトル図 
斜面ベクトル図は，第 1 図に示す $I_{0}=1.0$ のときの円形カ ラーチャートで表現してある。斜面ベクトルの立体視対 （第 3 図）を立体視すると，傾斜方向，傾斜量，標高の空 間的変化を 1 枚の地図で容易に認識することができる。

まず，筑波山周辺の傾斜方位図㧍よび傾斜量図と斜面心゙ クトル図とを比較する。傾斜方位図には，傾斜方向のみが 表示されている，傾斜量図には，地形の傾斜量のみが表示 されている，標高図や陰影図を参考に傾斜方位図を見る と, 斜面の連続性の抽出に有効であり, 谷線・尾根線を含 む線形構造がよく分かる。しかし，平野と山地の区分が不 明瞭で，また斜面の凹凸も不明瞭である。傾斜量図は平野 と山地が明瞭に区分されている。また，谷線・尾根線を含 む線形構造や段丘崖も明瞭に認識できる。ただ，山地で は，地形の起伏が不明瞭である。対して，斜面ベクトル図 を見ると, 谷線・尾根線を含む線形構造が明瞭で, 山地, 平野，段丘崖の区分も可能であり，地形の違いが明膫に識 別できる。これらのことから，斜面べクトル図は，傾斜方 位図と傾斜量図の長所を合わせもつ上に，地形の起伏も表 現していることがわかる.

次に，標高図および除影図を斜面ベクトル図と比較す る。標高図は，地形の外観を見るためには一般的なもので あるが，標高図から特徵的な地形を判読するためにはある 程度の熟練を要する。また，標高図から特徽的地形を定量 的に抽出することはさらに難しい，陰影図は，影を付ける ことで地形の凹凸が立体的に見えるという点で, 線形構造 の抽出や地形の外観把握に優れている。しかし, 光の照射 方向に平行する線形構造が捉えられないことや，陰になる 部分の地形が不明瞭であるという久点がある。このため線 形構造や地形の变化を方向に関係なく抽出するためには, 複数の方向からの光源を想定した多くの画像を見なければ ならない。攵の点，斜面ベクトル図は 1 枚の図で線形構造 などの特徵的地形や地形の変化を表現している上に, 定量 的に扱うことも可能である。 また，斜面べクトル図はカラ 一図であるため，人間の直感的な認識を助け，見落としが 少なくなることが期待できる.

斜面べクトル図は, 単独で傾斜方向, 傾斜量, 地形の変 化などを表現することが可能で, 線形構造などの特徵的地 形の抽出に適していることがわかった。しかし，正確に地 形の変化を認識するためには, 円形カラーチャートの色相 と傾斜方向の対応付けを参照する必要がある。この煩雑さ を防ぐために，斜面べクトルに対応する色がつけられた地 形を想定して，これを立体視することにした。これによ り，地形の変化がより容易に認識できる(第 3 図).

斜面ベクトル図が線形構造の抽出に適していることを確 かめるために, 大分県万年山周辺の陰影図, 傾斜方位図, 傾斜量図，斜面べクトル図（第4図）抢よび立体視対（第 5 図）を作成した。まず，第 4 図の斜面べクトル図を見る と, 万年山の西〜南西部 (A) と北東部 (B)に扔いて, ほぼ東 西に走る線構造（青）が見られる。これら東西に走る線構 造は, 南〜南西向きの幅の狭い急峻な斜面の連続であり,
本地域に多数発達している東西に走る正断層（町田ほか, 2001）に対比される。また，南北に走る線構造（赤）が青 で示す線構造と交差している。これらの赤で示された線構 造は東向きの幅の狭い急斜面の連続である。このことは, 第 5 図の立体視対を用いて立体視して見るとさらに明膫に 認識できる。これらの線構造は, 立体視からわかる地形の 特徽からも，断裂構造を捉えている可能性が高い。また， (A)では, 東西方向の線構造である青い線が南北方向の赤い 線構造を連続的に分断しているようにも見える。

次に, 第 4 図の陰影図と斜面ベクトル図を比較する。陰 影図（第 4 図の $\mathrm{a}$ と $\mathrm{b}$ ）を見ると，光源が北側にある場合 は (A)，Bの区域に見られる東西方向の線形構造が鮮明に認 識できるが，光源が南東側にある場合はかなり不鮮明であ る. 対して, 斜面べクトル図ではさまざまな方向の線形構 造が色相の違う線で全て同時に表現されている。さうに， 斜面ベクトル図を，傾斜方位図㧍よび傾斜量図と比較する と, 傾斜方位図は, 傾斜方向の連続性の抽出には適してい るが，傾斜角が急峻な部分のみを抽出することは不可能で あり, 抽出される断層の幅が実際より広くなる。一方, 傾 斜量図では，さまざまな方向性を持つ斜面が混在している 場合，傾斜方向の識別ができず線形構造の連続性を追いに くい. 断層の抽出で斜面ベクトル図が傾斜方位図や傾斜量 図より優れているのは，第6図を見れば明らかである。例 えば，両側が同程度の傾きをもつ谷の断面の場合，傾斜方 位図（a）では，傾斜方向のみによって色分けされ，同じ 傾斜方向を持つ斜面は同じ色相と彩度で表現されるため, 抽出された線構造の幅が広くなる。傾斜量図（b) でも谷 線の両側の斜面が同じ色相と彩度で表現されるため, 抽出 された線構造の幅が広くなる。これに対し, 斜面べクトル 図（c）では，傾斜角が大きい部分は彩度が高く，傾斜方 向が色相で区別されるため, 推定される断層の幅がシャー プになる。

環状構造の抽出にも斜面ベクトル図は有効である。第 7 図に十和田湖周辺の傾斜量図と斜面ベクトル図が，第 8 図 にその立体視対が示してある。第 7 図の傾斜量図と斜面心゙ クトル図を比較すると，傾斜量図は環状構造を形成してい る急峻な傾斜面の連続をよく表現している。しかし，環状 構造の内側が陥没しているか隆起しているかの判断は難し い. 斜面ベクトル図でも, 傾斜の急峻な部分は彩度が大き いため環状構造は抽出される。さらに，斜面ベクトル図で は，傾斜の方向がわかるので，陥没構造と隆起構造の識別 が可能となる．また，斜面べクトル図を立体視することで 陥没構造と隆起構造をより容易に認識できる.

\section{5. まとめ}

斜面ベクトル図とその立体視対を作成した結果，以下の ことがわかった。

(1) ウルフ網とHSI 円錐カラーモデルの底面を対応させ て斜面ベクトルを色で表し，これを地図として表現 すると, 傾斜方向, 傾斜量, 地形の変化を同時に表 


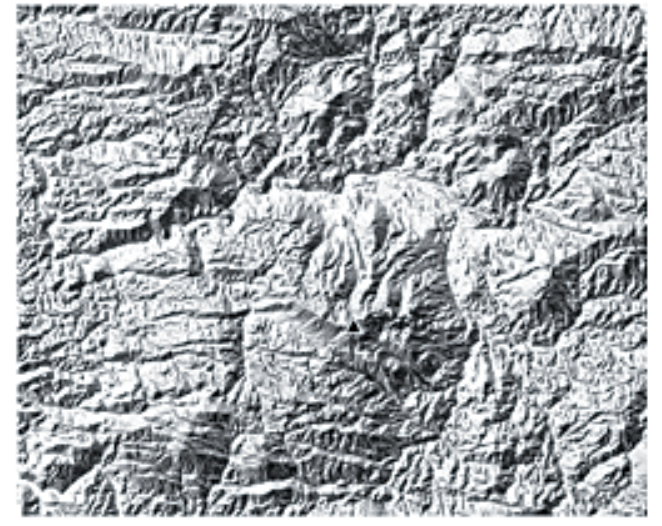

a 陰影図 (光源：北)

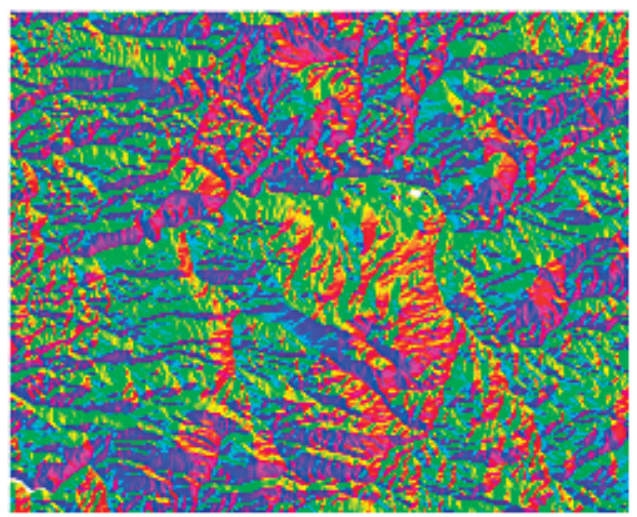

c 傾斜方位図

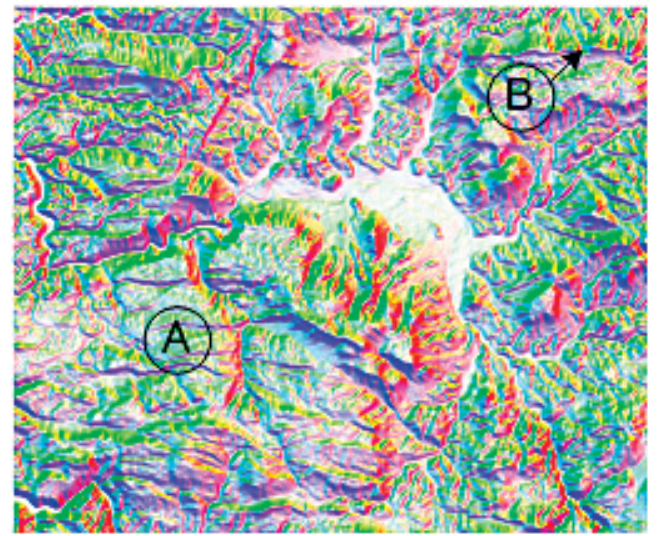

e 傾斜ベクトル図

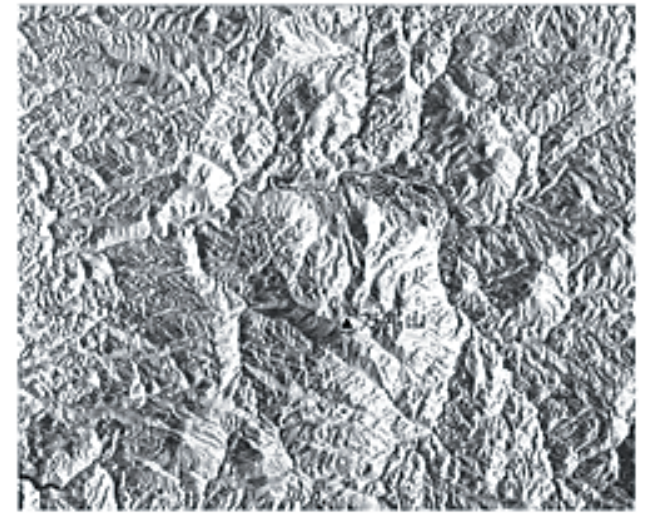

b 陰影図 (光源：南東)

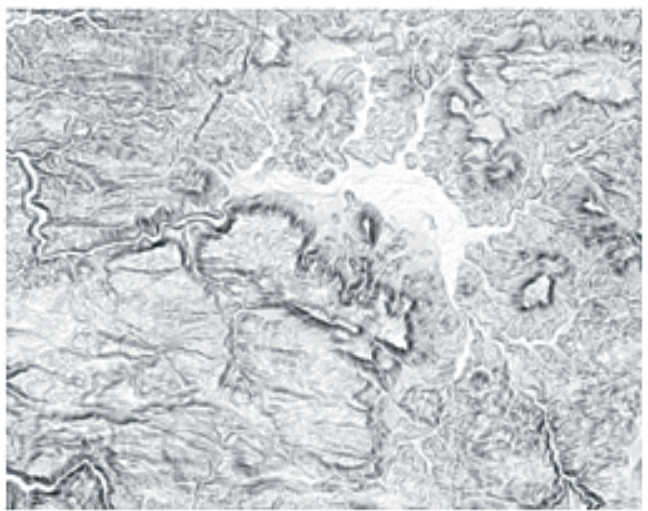

d 傾斜量図

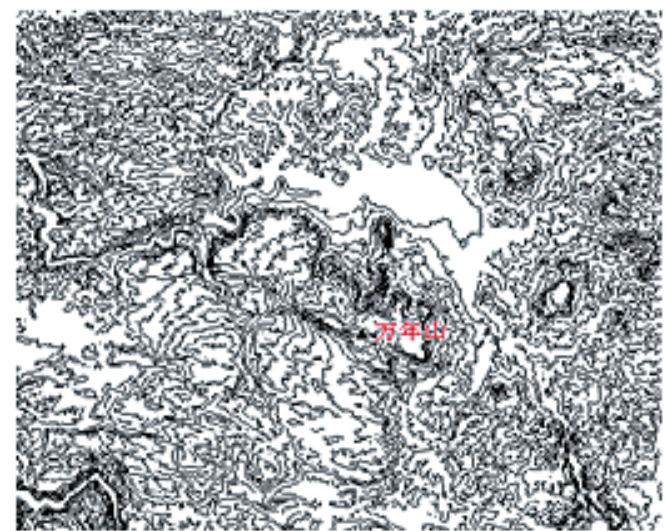

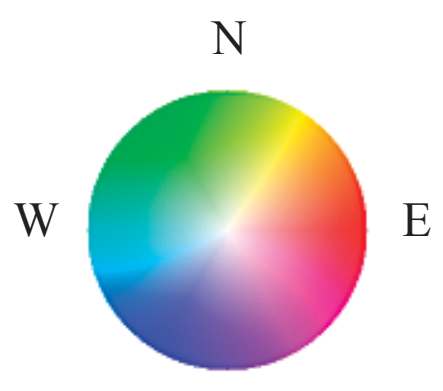

S

第 4 図 万年山周辺の地形解析図（東西：約 $23.3 \mathrm{~km}$ ，南北：約 $18.5 \mathrm{~km}$ ) 

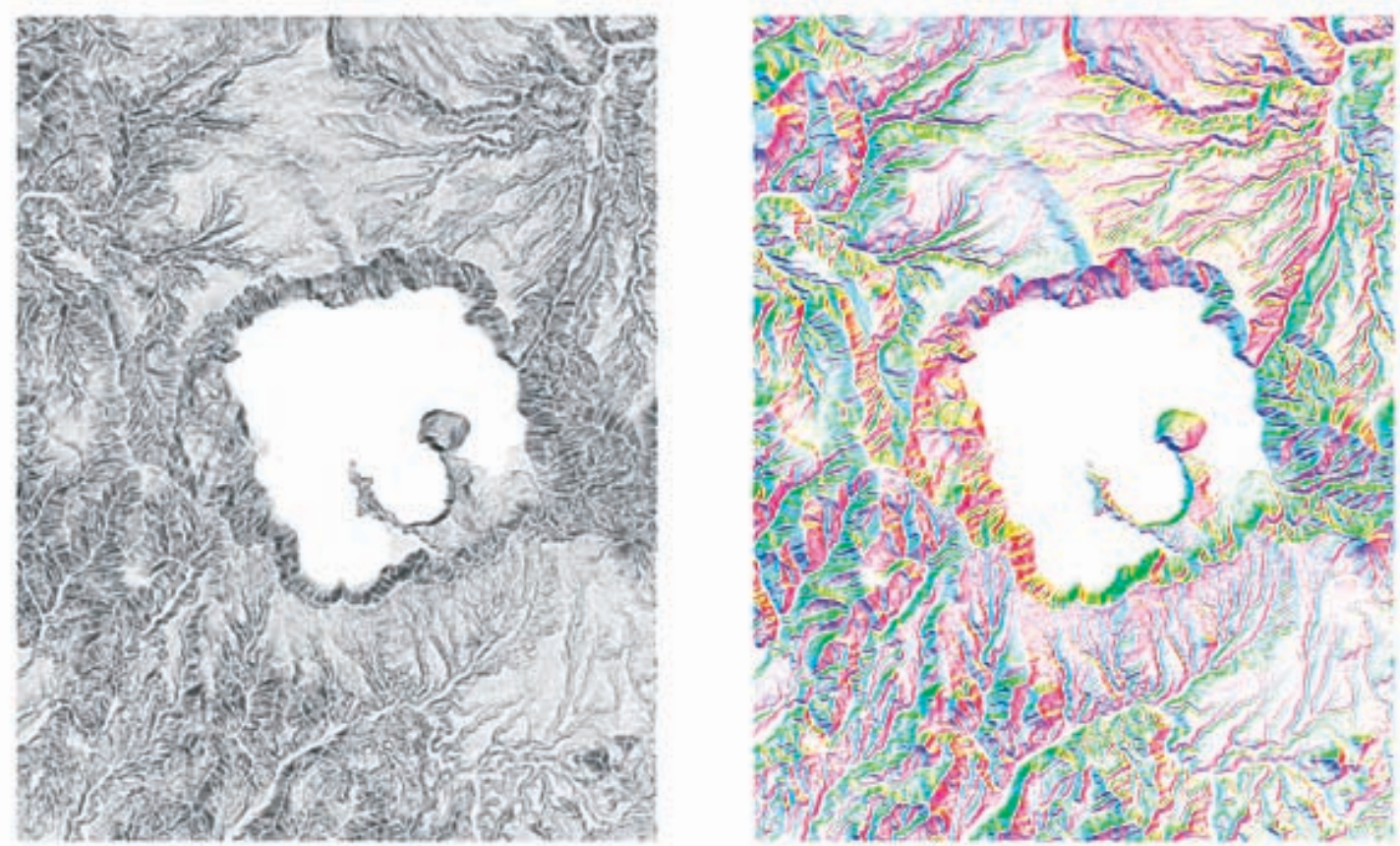

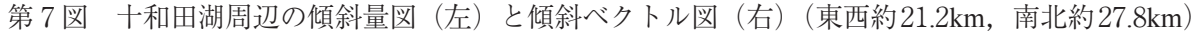
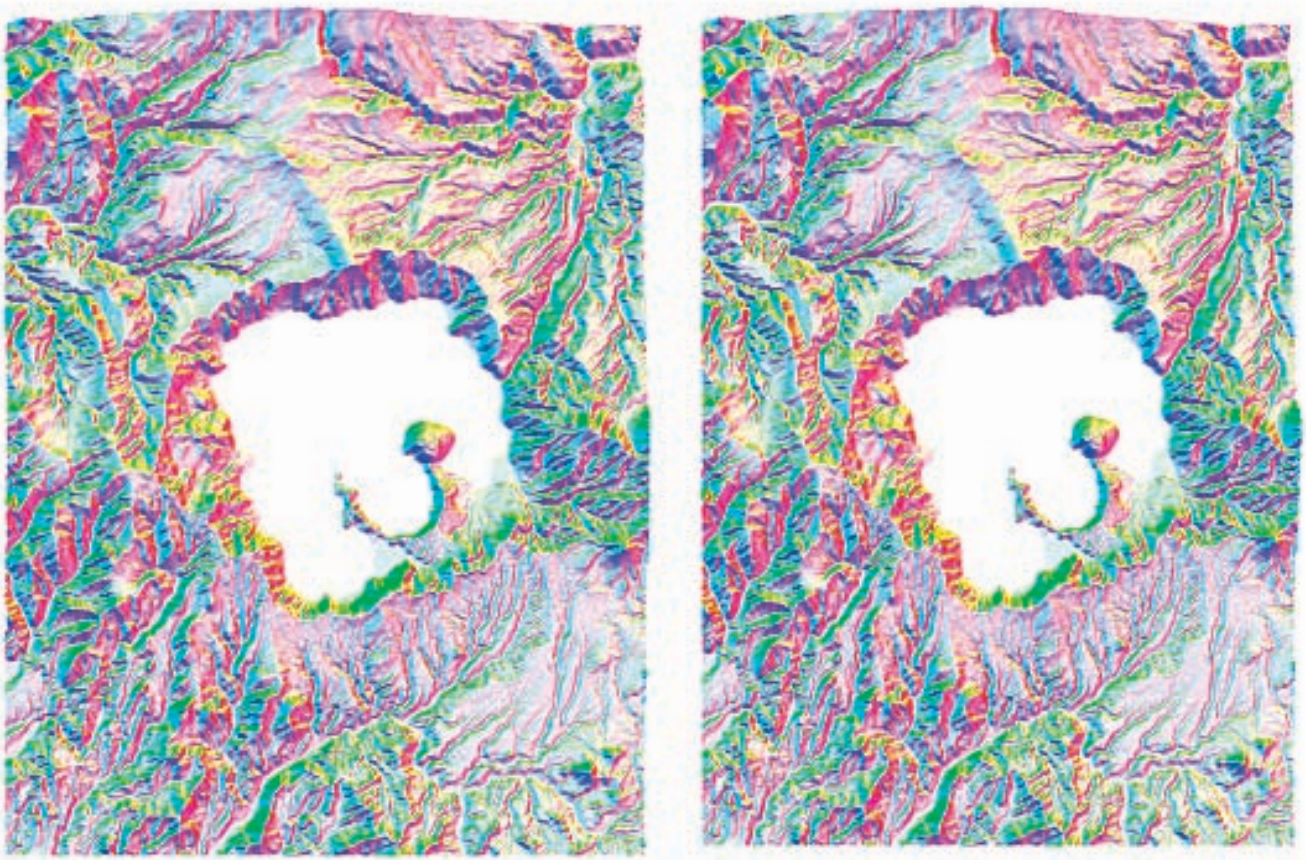

第 8 図 十和田湖周辺の立体視対（東西約 $21.2 \mathrm{~km} ，$ 南北約 $27.8 \mathrm{~km}$ ) 
現できる。この図を斜面べクトル図と名づけた。

（2）斜面べクトル図を，地形が立体視できるように立体 視対として表現すると，断層帯などの特徽的地形が より容易に抽出できる。

\section{文献}

羽坂俊一・渡辺 寧 - 池田国昭 (1991) 地形数值デー夕を 基にしたリニアメントの抽出 -2 万 5 千分の 1 地形図「余 市岳」での応用例一. 地質調查所月報, vol. 42 , no. 1 , pp. 11-17.

Hobbs, W. H. (1904) Lineaments of Atlantic Border Region. Bull. Geol. Soc. Amer., vol. 15, pp. 483-506.

井上大榮・水落幸広・桜田裕之（1992）リニアメントの断 裂系としての特性とその評価. 応用地質, vol. 33, no. 3, pp. 25-34.

岩橋純子（1992）ディジタルフィルタを用いた数值地形モ デルの地形解析. 情報地質, vol. 3, no. 1, pp. 31-37.

神谷 泉・黒木貴一・田中耕平 (2000) 傾斜量図を用いた 地形・地質の判読. 情報地質, vol. 11, no. 1, pp. 11-24. 町田 洋 · 太田陽子·河名俊男 · 森脇 広 · 長岡信治 (2001) 日本の地形 7 九州・南西諸島. 東京大学出版会, 355p. 大地正高 - 駒井二郎 - 新井勝男 - 藤岡洋介 徳尾貴昭 - 大 谷健二（1987）衛星MSS データからのリニアメント自動 抽出とその地質学的評価。鉱山地質, vol. 37 , no. 2, pp. 99-108.

田中耕平・幾志新吉・熊谷貞治（1985）三宅島の傾斜分布 図. 国立防災科学技術センター研究速報, no. 69, pp.7-27.

\section{要 旨}

特徵的地形抽出のための斜面ベクトルのカラー表示とその立体視

: 中村 貴子・正路 徹也

傾斜面の法線ベクトル（すなわち，斜面ベクトル）をHSI 錐カラーモデルの底面に描いたウルフ網上の点に対応 させることにより，斜面べクトルは地図上の一点に色で表示される。したがって，傾斜方向と傾斜量の空間的分布が 同時に表現される。この図は, 単独で傾斜方向, 傾斜量, 地形の変化を表現することが可能で, 断層やその他の線形 構造, 環状構造などの特徵的地形の抽出に適している. また, 斜面べクトル図で着色した地形表面の立体視対を作成 すると，特徵的地形の抽出がさらに容易になる。

キーワード：斜面ベクトル，ウルフ網，HSI円錐カラーモデル，立体視対 